JOURNAL OF SECURITY AND SUSTAINABILITY ISSUES

ISSN 2029-7017 print/ISSN 2029-7025 online

2021 Volume 11

https://doi.org/10.47459/jssi.2021.11.18

\title{
POLEMOLOGICAL RESEARCH AND DEVELOPMENT FACILITIES AND INSTITUTIONS - WAR STUDIES
}

\author{
Lukasz Roman \\ Academy of Justice, 50 Wiśniowa Street, 02-520 Warsaw, Poland \\ E-mails:lukasz.roman@swws.edu.pl
}

Received 8 October 2020; accepted 28 March 2021; published 30 June 2021

\begin{abstract}
The article presents an in-depth identification of the polemological aspects of research on the subject of wars and armed conflicts of the $21^{\text {st }}$ century. Moreover, it discusses the evolution, scale and nature of contemporary, as well as future wars and armed conflicts. The article refers to the essence, properties and characteristics of 'new wars' and the possibility of studying them by using appropriate instruments. Based on the conducted research, an attempt is made at forecasting wars and armed conflicts of the future. The article also highlights the activities and functioning of contemporary research institutes and facilities engaged in the analysis of war and armed conflicts, and focuses on the legitimacy and needs of implementing the polemological approach to the research of the presented subject in the present global-informational security conditions.
\end{abstract}

Keywords: war; armed conflicts; polemology; security science; facilities and institutions of polemological research

Reference to this paper should be made as follows: Roman, Ł. 2021. Polemological research and development facilities and institutions - war studies. Journal of Security and Sustainability Issues, 11, 215-226. https://doi.org/10.47459/jssi.2021.11.18

JEL Classifications: H56

Additional disciplines: security sciences, political sciences

\section{Introduction}

The analysis of the nature and essence of wars and armed conflicts is addressed by many specialists from different fields and scientific disciplines (Kriviņš et al., 2021). It can also be argued that research on these phenomena depends on the object and scope of cognitive interest (Chehabeddine, Tvaronavičienè, 2020). Moreover, polemology, in contrast with the art (science) of war, constantly seeks to unravel the quintessence of armed conflicts and wars in a universal manner, while using interdisciplinary research results.

Being a phenomenon that accompanies humanity since the dawn of history, war is an extremely difficult and multidimensional object of interest for researchers, and at the same time poses a great challenge. This is due to the fact that it affects almost all areas of life within the state and the society.

\section{Research aspects of war and armed conflict - an outline of the problem}

The vast majority of war theorists, polemologists and historians specialising in the phenomenon of war agree that war emerged at a stage in the development of societies when the conditions for the acquisition and accumulation of material goods and other types of value became more favourable [Polak, 2010, p. 61]. Hence, it has been a focus of investigation for philosophers, sociologists, historians, military theorists and polemologists since antiquity. 
If we were to accept the premise that wars have been an inseparable feature of humankind since the first societies began to emerge, then we can also estimate that the reflections on their genesis, essence and consequences started at the same moment. For many years, there has been a continuous quest for answers to the questions of why conflicts erupt, what their course depends on, and how to proceed in the most effective way and mitigate their negative consequences. Questions were also asked about what can be considered a just war, how the warring parties should behave towards each other, both when it comes to soldiers and civilians. Finally, war as a phenomenon of social life was subjected to analysis.

It is also advisable to provide an interpretation of the polemological approach in which the causes of wars and armed conflicts are studied with regard to many spheres of social life.

When identifying the causes of wars, it is assumed that they are concentrated on the following levels:

- structural causes which depend on the level of intellectual, technical, economic, agricultural and industrial development, demographic situation, historical circumstances and geographical conditions

- business-cycle causes, which result from imbalances, from encounters and clashes between human groups, each following a path of its own development. Hence the consequent discrepancies, tensions, intensification or relaxation of the desire for power;

- incidental (direct) causes - unforeseen incidents, provocations, etc. [Kęsoń, 2015, p. 14]

In prospection - research in the predictions of possible war threats - polemology uses five polemological barometers:

- geographic / geopolitical factors (political and geographic features, space and time),

- long-term factors (periodicity of wars),

- business-cycle factors (forming alliances, agreements and coalitions, the behaviour of public opinion under the influence of propaganda and ideology)

- barometers of national structures (related to the state structure, its features, statistical indicators of development)

- short-term barometers (sphere of motivation, transforming dispersed aggressiveness into active hostility). [Kęsoń, 2015, p. 14; Budzowski et al., 2008]

It can be argued that the presented polemological approach should be applied, first of all, to deepen the knowledge of armed conflicts and wars, to search for and learn about their causes, factors, their placement in time, as well as to anticipate their possible and future occurrence.

Nowadays we certainly still have more questions than answers with respect to the field of war and peace studies. If we take a closer look at the situation, we realise that, despite the immense progress that was made in the world at the turn of the $21^{\text {st }}$ century, the doubts we raise remain the same as those that preoccupied the people who addressed this issue hundreds or even thousands of years earlier.

Why do long-running wars still break out today despite the international law? How to define war today?

What criteria must be met by today's just war, whose idea arose during the reception of Christianity, which had been pacifist to date, as a state cult? Is it fair to take actions like 'humanitarian intervention' or the overthrow of a regime that potentially threatens the international community? How to orient the law of armed conflict towards the new challenges of the modern warfare, particularly related to the dehumanisation of war through the increased use of unmanned vehicles? How to treat an aerial drone operator, sitting in the USA, who decides on the life or death in the other hemisphere with the push of a button?

Last but not least, if we regard war, or at least the possibility of it, as an indispensable part of today's world, how should the modern world effectively prepare for it? 
Certainly, we are constantly seeking answers to these and many other questions, and the historical experiences of past wars and armed conflicts show us the harsh reality as, in spite of analyses and multifaceted evaluations, we are still unable to eliminate armed violence in resolving conflict situations of different backgrounds, causes and scope.

This negative phenomenon has become an integral part of how humanity has functioned throughout history. With the general condemnation of the use of armed violence and the dynamic efforts of the international community for the sake of peaceful coexistence, wars and armed conflicts continue to occur.

One might even conclude that the world has come to terms with the fact that this is such a complex problem that it cannot be solved once and for all. On the other hand, it was considered feasible to achieve objectives that minimise all risks of conflict and war. With this in mind, various security systems are being created with the overriding aim of ensuring peaceful conditions for the development of societies.

\section{Research and development institutes and facilities - war studies}

The theoretical knowledge which encompasses the science of war is expanded and enriched by the use of available interdisciplinary research achievements in the field of war and armed conflicts.

Polemological research is carried out by research institutes and facilities all over the world. In an effort to identify these centres outside Poland, we encounter certain difficulties, especially with regard to the manner in which they currently function. We have information from 1995 and 1998, which suggests that the most renowned polemological institutes were active in France (Institut Français de Polemologie - Paris), the Netherlands (Polemologisch Institut in Groningen), Italy (Instituto Italiano di Polemologia - Milan), Spain (Institut de Polemologia Wiktor Seix - Barcelona), as well as in Belgium, West Germany, Switzerland, Canada, Mexico and Brazil. [Kęsoń, 2015, p. 134]

Currently in operation is the Polemological Centre - Free University of Brussels [Mojsiewicz, 1998, p. 135], which conducts research in the social sciences, political science and administration, as well as in the field of polemology. Polemology focuses primarily on security policy, the phenomenon of war, armed conflict and peace. The Polemological Centre mainly provides a forum for multilateral cooperation and conflict regulation with other research centres [Huzarski, 2015, p. 37].

The Polemological Institute at the University of Groningen in the Netherlands was established in 1962 by the aforementioned lawyer Bert Röling. It focused its activities within the field of polemology primarily on interdisciplinary research in the field of war and peace. The Institute of Polemology in Groningen was renamed International Security Studies in 1993, with a special focus on the impact of environmental change [Huzarski, 2015, p. 37].

The following is a selection of the scientific output of the Institute of Polemology at the University of Groningen in the Netherlands:

- Johan Galtung, Polemologia - kwestie wojny i pokoju [Polemology - the Issues of War and Peace], ed. Polak \& van gennep, Amsterdam (1968),

- B. Röling, Wprowadzenie do nauki o wojnie i pokoju [An Introduction to the Science of War and Peace], ed. Van gorcum, assen (1968)

- Hylke Tromp, Badania krytyczne polemologii w polityce, pokoju i przemocy [Critical Polemological Studies on Politics, Peace and Violecne], ed. Van gorcum, Assen (1973) ISBN 90-232-0995-8,

- B. Röling, Idea edukacji w sprawach karnych [The Idea of Education in Criminal Cases]. Hague, Nijhoff, 1983. (An inaugural speech in Utrecht),

- Polemologiczne studia w Amsterdamie. Kontrowersje polemologii [Polemological Studies in Amsterdam. Controversies of Polemology], Amsterdam (1970) ISBN 90-6172-011-7. 
Another famous scholar in the field of polemological research - Leon Wecke was the founder of the Centre for Peace Research at Radboud University in Nijmegen, the Netherlands, present day Centre for International Conflict - Analysis \& Management, CICAM).

The Centre for International Conflict - Analysis and Management is a politically independent research institute that pursues interdisciplinary analyses of various aspects of international relations. CICAM conducts research and training in the fields of peace, security, war and armed conflict. In addition, CICAM has specific tasks in the field of social welfare and education with respect to peace and security issues for students [RU.NL, 2020].

CICAM research centres on the analysis of contemporary armed conflicts and initiatives to support and promote peace. CICAM researchers investigate these phenomena from the perspective of actors in the conflictaffected countries [RU.NL, 2020].

Research conducted by CICAM specialists most often takes the form of:

- critical analysis of dominant discourses, frameworks and approaches to conflict analysis, peacebuilding and development,

- field and qualitative research in conflict-affected countries (with the application of the methodological approach).

The most important aspects of the research conducted by CICAM scholars include:

- local processes of state formation and various efforts in legitimising public power, involving state actors, civil society groups, local institutions and international organisations,

- the role of civil society and social movements in the conflict, including peacebuilding activities,

- peacebuilding discourses and practices,

- everyday practice of state-building, governance and security in border areas [RU.NL, 2020].

CICAM offers undergraduate and postgraduate training in the dynamics of war, peace and security in military intervention, development aid, as well as aid provided to civil society organisations in conflict-affected areas [RU.NL, 2020].

Classes and faculties at Bachelor's and Master's level are taught in English and Dutch. However, undergraduate courses are offered only in English, and the most important subjects and courses taught at the undergraduate level include [RU.NL, 2020]:

- Approaches to Peacebuilding (first cycle, 6 ECTS)

- Armed Conflict and Governance in Africa (first cycle, 6 ECTS)

- Introduction to Conflict Analysis and Management (first cycle, 6 ECTS)

- Peacemaking Negotiations (first cycle, 6 ECTS)

- War in Afghanistan (first cycle, 6 ECTS)

In collaboration with the Department of Geography, CICAM also runs a major programme on "Conflicts - Territories and Identity. This one-year graduate course provides students with education in political and geographical science on the study of conflict, peace, borders and development [RU.NL, 2020].

The main courses in the major programme include:

- Conflicting Theories (Second Cycle, 6 ECTS)

- Political and Geographical Conflict Resolution (Second Cycle, 6 ECTS)

- Conflict, Aid and Development (Second Cycle, 6 ECTS)

- Educational Visit to a Post-Conflict Region (Second Cycle, 6 ECTS)

The University of Strasbourg in France has almost five centuries of history, famous names, a rich heritage, a strong position in Europe. The university currently claims 52,000 students, 20\% international students, 5300 
researchers and teachers, 35 units of training and research, 72 research units. These impressive numbers make the University a rich and diversified space in a multidisciplinary offer of training and research [Unistra.fr, 2020].

One of the most important faculties at the University of Strasbourg is the Faculty of Social Sciences, which consists of six institutes [Unistra.fr, 2020]:

- Institute of Sociology

- Institute of Demography

- Institute of Ethnology

- Institute of Polemology

- Institute of Urban and Regional Planning

- Institute of Social Research and Intervention

The Institute of Polemology aims to update and disseminate knowledge to fully understand and conduct research in the field of war and armed conflict. The Institute of Polemology was established n 1970 by J. Freund, who right from the outset sought to conduct research as a continuation of the work by G. Bouthoul on war as a social phenomenon. The Institute of Polemology is primarily concerned with the development of the science of war and the conduct of scientific research in the field of modern wars and armed conflicts [Unistra.fr, 2020].

The Institute for Strategy and Conflict operating in France, which is an independent and leading research centre on strategic issues, is also particularly noteworthy [Institut-strategie.fr, 2020].

The most important research areas of the Institute include [Institut-strategie.fr, 2020]:

- polemological research and studies,

- strategic studies,

- military geography,

- art of war and its theorists,

- terrorism,

- modern wars and armed conflicts.

Major publications of the institute [Institut-strategie.fr, 2020]:

- Polemological studies

- Prospective Sources and Strategic Quarterlies / Reviews (since 1979)

Foreign research institutions that deal with polemology include the Institute for the Study of War in Washington, D.C., which focuses its activities on military issues through credible research, analysis and innovative education. The Institute is non-partisan and conducts public policy as a research organisation [ISW, 2020].

The Institute for the Study of War conducts detailed intelligence analysis to provide the most accurate information on current conflicts and security threats. Institute researchers focus their research on conflict zones by conducting independent assessments. The Institute aims to promote an informed understanding of the phenomenon of war, armed conflict and military affairs through comprehensive, independent and accessible research [ISW, 2020].

The Institute's findings are made publicly available to e.g. medical officers, politicians and media representatives [ISW, 2020].

The area of conducted research primarily covers [ISW, 2020]:

- the current geopolitical situation in the world,

- analysis of wars and armed conflicts in the Middle East - Afghanistan, Iraq. 
In the UK there is a Department of War Studies based at King's College London. It is the largest and one of the most widely known European university groups, where specialists focus on research in relation to all aspects of war, armed conflict, peace, security and international relations in the past, present and future.

The main research centres and study areas of this unit include:

- Centre for Defence Studies (CDS)

- Centre for Science \& Security Studies (CSSS)

- European Centre for Climate, Energy and Resource Security (EUCERS)

- International Centre for the Study of Radicalisation (ICSR)

- Centre for Military Health Research

- Centre for Armed Conflict and Security Research

- Research Centre in International Relations (RCIR)

- Sir Michael Howard Centre for the History of War

Research Groups:

- Afghanistan Research Group

- Polish Research Group

- Asian Security \& Warfare Research Group

- Conflict, Security \& Development Research Group (CSDRG)

- War Crimes Research Group

In Ireland, on the other hand, there is the Centre for War Studies, which has its headquarters at the University College Dublin. It focuses its scientific activities primarily on interdisciplinary research and seeks to develop new research projects in collaboration with other research institutions in Europe and North America.

The Centre for War Studies builds on the existing research interests of a significant number of staff in the fields of history, sociology and politics, and serves as a forum for students, teachers and lecturers on the history of war and interpersonal violence.

The Centre for War Studies organises a number of conferences and academic seminars on issues of war and armed conflict in Central and Eastern Europe and all around the world (World War I and World War II, and postWorld War II conflicts), as well as on warfare and military operations. The Centre for War Studies publishes a series of articles by both foreign as well as Polish scientists. Additionally, the Centre for War Studies organises a fortnightly series of seminars where researchers from various scientific disciplines present papers on their current research, also in an online format.

Among universities and research centres dealing with polemology, it is also worth mentioning Polish research units dealing with this issue. The Department of the History of War Art deserves a distinction and Polemology of the Institute of Military Strategy of the Military Academy in Warsaw, the aim of which is to enrich and promote knowledge in the field of the history of the art of war, polemological theories, to identify and understand the nature of wars and armed conflicts of the past and contemporary, as well as to conduct assessments of phenomena and symptoms generating conflict situations in cooperation with other scientific and research centres.

The mission of the Department is to conduct scientific research and develop knowledge in the field of the history of the art of war and polemology, the determinants of the emergence and evolution of wars and armed conflicts and their impact on shaping international security over the centuries.

The aim of scientific and research activity is, above all, to detect, learn and explain regularities and to formulate theories related to the development of the art of war and the evolution of wars and armed conflicts. An important section of the subject of research is also the implementation of tasks related to scientific advice and expert activity in the field of creative use of conclusions drawn from the history of the art of war and polemological 
analyses of wars and armed conflicts. Cognitive curiosity in the research process is focused on popularizing knowledge in the field of military history and polemology, especially the history of martial arts and the history of wars.

The mission of the Department is to enrich and promote scientific achievements in the field of the history of the art of war and polemology, to identify and learn about the nature of wars and armed conflicts in the past and now, as well as to conduct an assessment of phenomena and symptoms generating situations causing wars and armed conflicts.

The department conducts scientific activity focusing its interests, among others, on the development and search for the regularities of forms of armed struggle and on the generalization of historical experiences of modern wars and armed conflicts and determining their impact on the preparation and conduct of modern warfare, taking into account the new military technique and organizational structures of the armed forces.

Teaching activities are focused on educating students (doctoral, master's, undergraduate and postgraduate studies) and students of specialist courses in the history of war art and polemology. The aim of the didactic activity is, above all, to equip students and learners with the necessary knowledge and skills in the above-mentioned areas. This will allow for their creative use in analytical and design teams, in institutions and universities, as part of systemic activities for the development of the armed forces and national security.

The didactic activity of the Department focuses on the following subjects: history of the art of war, military thought, polemology, contemporary armed conflicts, methods of analysis of contemporary armed conflicts, theory of guerrilla and counter-insurgency activities, conflicts in the Arctic region.

After a review of available information on scientific and research centres engaged in studying the phenomenon of war in its various scopes, it can be concluded that there are sufficient (although incomplete) grounds for formulating assessments and conclusions on the relevant topic.

The presented current state of polemological knowledge provides a certain platform for making assessments and forming views on the legitimacy of practising this branch of science. The growth of polemological knowledge takes place as a result of scientific and journalistic activities, the implementation of the didactic process, promotion of the staff and promotion of the development of this field. It was previously assessed that polemology encompasses the study of war and conflict and how to prevent, resolve and avoid them. It finds aspects of security through the analysis of these phenomena.

Based on the above information, we can see a continuing interest in the study of issues related to war. They are not called polemology, but their purpose and goal is to seek to learn about the phenomenon of war with the intention of using this knowledge for the sake of peace. It can be assumed that there is an exchange of experience and cooperation between the above-mentioned centres and the Polemological Centre - Free University in Brussels.

\section{A perspective on armed conflicts in the 21 st century}

In the context of current security conditions characterised by globalisation trends, emerging wars and armed conflicts are diametrically different from the traditional ones that were the focus of war theorists and polemologists following World War II.

In many source materials we encounter the term 'new wars'. It is assumed that "they are waged for particularistic purposes, often using instruments of terror and violation of the laws of war, not infrequently to satisfy the needs of informal, criminal groups [Kostecki, 2012, p. 121]

These are mostly civil wars, sometimes referred to as 'privatised wars' or 'informal wars'. In such wars there are usually no fronts, strategy or tactics. There is also no clarity as to who is fighting whom or what for, and why 
soldiers want to take part in them. Wars such as Rwanda (1994), Bosnia (1992-1995), Somalia (1994-1995) with hundreds of thousands of casualties, are subject to analysis here [Kostecki, 2012, p. 121].

The future 'new war', as an extremely complex, interdependent and dynamic phenomenon, requires a systemic and comprehensive approach in analyses and evaluations. It should be assumed that a condition for the existence of war is the existence of two antagonistic sides. Therefore, its basic participants, driven by contradictory goals, aspirations and motives, must be distinguished. Due to the fact that the structure, shape or form of war is constantly evolving (each epoch has its wars), this obviously does not exclude the existence of other types of war, which are now difficult to characterise unambiguously.

Over the centuries, war has evolved - it has undergone numerous transformations, its character, form and ways of fighting have changed. Their objective has remained the same - the pursuit of goals, aspirations, economic, political, ethnic, social and other interests.

Predictions about wars of the future, wars of the XXI century seem to suggest that we can talk about one general model of wars. Probably now, as in the future, new forms of wars will appear, just as they appeared at the turn of the XXI century; however, the 'old ones' will not disappear for a long time, while the 'new' forms may have several varieties.

Based on the conducted research concerning the evolution, scale and character of future wars and armed conflicts, specialists advocate the theory that on the basis of changes in the contemporary world we can pose a thesis that global conflict is not possible, because it would mean the development of divisions in formalized opposing organizations that have the political will to rule the world. Local ethnic conflicts are still likely in areas with a low level of state-forming tradition. Conflicts that aim to achieve individual goals by temporarily violating the sovereignty of a given state are particularly dangerous. This type of action will apply equally to states with a high level of civilisational development and those with civilisational backwardness. Having achieved its individual goal, the aggressor will perversely seek to legalise the illegal actions.

It is emphasised that the evolution of violence and war is becoming increasingly evident. Today's wars are decentralised, mostly civilisational, ethnic or religious in nature, and conflicts will become more localised. They will be sudden, violent and lawless. Africa is likely to be a leader with regard to areas beset by conflict. North America and Australia and Oceania will be the most stable continents. The Middle East will become (if it is not already) one of the most conflict-ridden parts of the world, with the spread of Islamic fundamentalism, the rivalry between Shiites and Sunnis, and the increased presence of terrorist groups, primarily the Islamic State.

The presented research outcomes are also confirmed by the current international situation, and furthermore, it can be concluded on the basis of the conducted research that the opinions of scholars, experts and practitioners in the field of armed conflicts and war emphasise that the armed conflicts that may take place in the world in the future will, to the greatest extent, be local, and later regional in nature.

Future 'new' wars and armed conflicts may appear suddenly, and their escalation may occur with different and dynamic intensity (Eastern Ukraine). There is every indication that they will be mainly short-lived conflicts of varying intensity (from hybrid wars to rapid short attacks by powerful forces). They will be mainly (because they already are) private wars fought with national armies and, as always, religious (long-lasting) and ethnic (extremely bloody) conflicts.

Moreover, future 'new' wars and armed conflicts will have features of asymmetric, hybrid and cyber warfare.

However, it can be understood that these will be multidimensional activities in five areas (land, air, sea, space and electronics). They will not be linear but dispersed. Their size can be rapidly transferred to other dimensions and areas. However, space battles have not occurred yet, nor have any major conflicts occurred in this environment, despite the fact that military rivalry has been extending into space for several decades. 
The armed conflicts of the $21^{\text {st }}$ century are not and certainly will not be pure in form. Confrontations will take place between both technologically equivalent and diverse armies. Because of this diversity of the opposing sides, armed conflict will take the form of combat with limited lethality and scale of destruction, war of attrition (lethal) and combined arms [Żebrowski, 2008, p. 220]. (Table 1).

Table 1. A perspective on wars and armed conflicts in the $21^{\text {st }}$ century

\begin{tabular}{|l|}
\multicolumn{1}{|c|}{ Analysis of future wars and armed conflicts in the $21^{\text {st }}$ century } \\
\hline - Local and regional conflicts \\
\hline - Civilisational, ethnic and religious grounds \\
\hline - The conflicts will become sudden, violent and lawless. \\
\hline - Decentralised wars \\
\hline - Future 'new' wars and armed conflicts will have features of asymmetric, hybrid and cyber warfare. \\
\hline - Future 'new' wars and armed conflicts may appear suddenly, and their escalation may occur with different and dynamic intensity. \\
\hline - The armed conflicts of the $21^{\text {st }}$ century are not and will not be pure in form \\
\hline - Conflicts of the future will take place in five dimensions: land, sea, air, space and electronics \\
\hline
\end{tabular}

Source: author's own work based on research

New wars are characterised not only by their duration but also by their distinctive features, which include:

- the impact of dislocation in time and space on their course,

- conducting guerrilla warfare,

- the use of unconventional means,

- surprise action

New wars, in general, are characterised by the absence of what characterised traditional wars. Moreover, they are distinguished by the stronger imposing its will on the weaker, the lack of a clear beginning and end, and inefficient decentralised administration [Kubiak, 2012, p. 101].

Selected issues related to new wars generally bring us closer to their essence. This creates grounds for stating that their diversity and unpredictability, as well as their complex character, do not enable a wide application of traditional research methods associated with social sciences, including those used in security and defence sciences. Nor can they be studied with the application of the traditional polemological approach. This leaves the possibility of conducting research with the use of selected or generated research methods, according to the emerging new and complex problems. Achieving the intended objectives may be feasible after applying the interdisciplinary approach together with the methods of related disciplines, while taking into account the reality of conditions for the emerging wars and armed conflicts of the $21^{\text {st }}$ century.

\section{Conclusion}

The subject of polemology is the war and armed conflict. Moreover, it addresses the interpretation of the causes and determinants of wars and armed conflicts, as well as their genealogy. Its intention is to study war in a similar way to how social phenomena are studied, by analysing its nature and background, location in time and space, intensity, cause-effect relationships and the creation of classifications. One of the main assumptions of polemology is the cognition of war and conflicts and, consequently, the cognition of peace.

Taking into account the assumptions of polemology, we can deduce that it is a field based on three important tiers:

- a holistic sociology of war, which focuses attention on the categories of battle,

- the team and the causes of war,

- prospection, which takes into account the polemological barometers. 
This article presents a distinctive identification of polemological knowledge together with the research instruments of the polemological approach. Such an approach creates favourable conditions for coordinating research efforts carried out in different fields and scientific disciplines for achieving goals that indicate the causes of emerging conflict situations and possible ways to prevent them. They can be an important source and basis for the expansion of knowledge in the area we are concerned with. War and peace, as phenomena which have a great influence on the fate of the whole humanity and every man, have been and will be the subject of interest for researchers from many fields of science. Researchers and scholars of various epochs have made efforts to understand and explain these complex social phenomena, their origin, essence, character, while at the same time searching for ways and means which could lead to the creation of guarantees of lasting and universal peace, security of states and nations.

While numerous analyses and evaluations have been carried out on past wars and armed conflicts, it is still impossible to eliminate armed violence when resolving conflict situations. This applies to conflicts of a political, economic, geographical or cultural nature. Despite the fact that over the years, mainly after the Second World War, the phenomenon of condemning armed violence has been initiated on a mass scale, which is manifested in the activities of international organisations, legal regulations and social actions, wars and armed conflicts still occur. It is therefore possible to assume that this issue is so complex and difficult to resolve that there will be no definitive end to it. In order to reduce the effects of the threats of war and conflict nowadays, it is necessary to take actions to minimise them. An example of such action is building security systems based on cooperation not only in terms of defence, but also in economic and cultural aspects.

War, as a social phenomenon, has accompanied mankind almost since the beginning of its existence. One can even make the statement that the history of man, humanity or civilisation is the history of wars. War has been present in all epochs or civilisations [Aron, 1995, p. 197].

It constituted a mechanism of social development where new and more perfect civilisations arose on declining and destroyed ones. The phenomenon of wars and armed conflicts has been, is and, in the foreseeable future, will be an important determinant that affects the functioning of the entire international environment. The evolution of wars has been constantly visible over the years, due to both technological and civilisational progress that shapes the methods and objectives of how it is conducted. The armed forces are the tool of state policy, including warfare, and their task is to protect the interests of the state by, i.a. waging armed conflicts. The army is therefore an instrument of politics which, by military means, makes it possible to achieve political and other goals.

On the basis of the conducted research, it is possible to generate some important characteristics that future armed conflicts will be characterized by, namely, they will take place in a different manner from the traditional understanding of traditional war, i.e.:

- these conflicts do not have to be international (the attacking forces may not formally represent any state authority recognized in the sense of international law,

- they may be characterized by a large scale in terms of the area of operation, the participating forces, the methods and means of combat used, the consequences and the widely understood military, political, social and economic costs,

- also in terms of the intensity of combat operations, decisiveness and ruthlessness, they will be inferior to conventional wars,

- armed aggression will be more like creeping into a war than striking by surprise, such methods and means of violence that will put the methods and means of armed combat to the margin will be much more frequent

- the forces and resources involved will be more dispersed and their intensity of use will often change in time and space,

- in low-intensity conflicts, all kinds of weapons will be used, especially chemical weapons (as they are some of the cheapest and most effective),

- quasi-terrorist operations will be possible,

- the concepts of attack and defence will be re-evaluated. It is possible that offensive and defensive operations 
will be conducted in the same way and will differ only by the purpose of operation,

- the purpose, location and use of reserves will also change as a result of conducting new forms of military operations (multidimensional, manoeuvre-raid, diversion-terrorist, guerrilla etc.) [Dworecki, 1996, p. 147-150].

The wars of the future will continue to directly or indirectly affect all planes and types of international relations and all actors involved.

The forecast of warfare in the $21^{\text {st }}$ century assumes that future wars will be fought through the use of all information and advanced technologies, including unmanned equipment, command automation measures, modern information systems and precision-guided weapons. The greatest threat is the growing likelihood of the use of weapons of mass destruction, especially nuclear weapons.

Military operations will span traditional and new environments, such as cyberspace, electromagnetic space and outer space. Rather than huge armies, they will make use of modular highly mobile task forces, integrated and interconnected by ICT networks to ensure efficient command and a high level of battlefield awareness.

It should be assumed, however, that the aim of warfare will not be the physical annihilation of the opponent through inflicting heavy losses and destruction, but depriving him of the will to fight. Nevertheless, future wars will continue to result in death, destruction, poverty and the demoralisation of societies.

At the same time, however, it is worth remembering that much of the advice once given by the classics of strategic thinking has by no means lost its relevance. Referring to Carl von Clausevitz's formula, it can be said that war has not changed a bit in its nature, and is still a continuation of politics conducted by other means although at the same time it is sometimes difficult to say, if we were only to look at what is happening beyond Poland's eastern border, what is still politics and what is war. [Okraska, 2014, p. 7].

\section{References}

Aron R.., Pokój i wojna między narodami [Peace and War Between Nations], Wyd. Centrum im. Adama Smitha, Warsaw 1995

Budzowski K, Maciąg Z., Majchrowski J. (ed.): Bezpieczeństwo - teoria i praktyka [Security - Theory and Practice], no. 1-2, Kraków 2008

Chehabeddine, M., Tvaronavičienė, M. 2020. Securing regional development. Insights into Regional Development, 2(1), 430-442. http://doi.org/10.9770/IRD.2020.2.1(3)

Cziomer E., Zyblikiewicz L., Zarys współczesnych stosunków międzynarodowych [An Outline of Contemporary International Relations], Wyd. PWN

Dworecki S., Od konfliktu do wojny [From Conflict to War], Warsaw 1996, p. 147-150.

Huzarski M., Polemologia. Poznanie fenomenu wojny dla idei pokoju [Polemology. Getting to know the phenomenon of war for the idea of peace], Warsaw 2015

Kęsoń T., Pojęcie konfliktu i wojny w literaturze. Podejście polemologiczne w badaniach konfliktów zbrojnych [The Concept of Conflict and War in Literature. The Polemological Approach in the Study of Armed Conflicts], Warsaw 2008

Kostecki W. Strach i potęga. Bezpieczeństwo międzynarodowe w XXI wieku [Fear and Power. International Security in the $21^{\text {st }}$ Century], Warsaw 2012

Kriviņš, A., Teivāns-Treinovskis, J., Tumalavičius, V. 2021. Issues of state and national security: Religiously inspired terrorism in the Baltic States: internal and external factors. Insights Into Regional Development, 3(1), 65-79. http://doi.org/10.9770/IRD.2021.3.1(4)

Kubiak M., Kulturowe państwa, Rozprawa naukowa uwarunkowania obronności [Cultural Conditions of the Defence of the State], no. 116 , Siedlce 2012 .

Okraska T. (ed.), Oblicza współczesnych konfliktów zbrojnych [Different Types of Modern Armed Conflicts], Katowice 2014

Polak A., Wojna jako wyzwanie dla badacza [War as a Challenge for the Researcher], Kwartalnik Bellona 2/2010. 
Łukasz ROMAN is the Doctor of social sciences in the field of defence sciences, specializing in polemology. A scientific degree obtained at the Faculty of Management and Command at the National Defence University in Warsaw. Completed master's studies at the National Defence University in the field of management, specializing in management and command. A graduate of the National Defence Academy. From 2014, a member of the Management Board of the European Society for the Development of Social Competences John Dewey. In 2020, he completed postgraduate studies in history and knowledge about society. In 2015-2019, a research and didactic worker at the University of Euroregional Economy named after Alcide De Gasperi in Józefów. In 2017-2019, the Dean of the Field Faculty of Social Sciences in Mińsk Mazowiecki. From January 2020, a research and didactic employee as an assistant professor at the Academy of Justice. Author of many publications on security, defence and polemology. In addition to polemology, he conducts research in the field of contemporary armed conflicts, war history, the state's defence system, national security, internal security, and political sciences.

ORCID ID: 0000-0002-4159-3557

This work is licensed under the Creative Commons Attribution International License (CC BY). http://creativecommons.org/licenses/by/4.0/ 